\title{
RESPONSE OF ARTOCARPUS HETEROPHYLLUS LAM. TO SOME NATURAL EXTRACTS AT THE EARLY GROWTH STAGES 1- VEGETATIVE GROWTH AND ROOT TRAITS
}

\author{
Amira S. Soliman $^{*}$; A.M.Z. Sarhan ${ }^{* *}$; A. Nabih ${ }^{* * * *}$; S.A. Gomma ${ }^{* * * *}$ and H.S.A. Elham ${ }^{* * *}$ \\ * Institute of African Researches and Studies, Cairo Univ., Egypt. \\ ** Ornamental Hort. Dept., Fac. Agric., Cairo Univ. Egypt. \\ *** Botanical Gardens Res. Dept., Hort. Res. Inst., ARC, Giza, Egypt. \\ **** Ornamental Plants and Landscape Gardening Res. Dept., Hort. Res. Inst., ARC, Giza, Egypt.
}

ABSTRACT: A field experiment was consummated at the nursery of Horticulture Research Institute, ARC, Giza, Egypt, throughout two successive seasons (2012/2013 and 2013/2014). It was intended to improve vegetative growth and root parameters of Artocarpus heterophyllus Lam. at the early growth stages by studying the effect of treating the plants with different natural extracts botanicals (Moringa oleifera, Lam., Thymus vulgaris, L. and Majorana hortensis, Moench) at the levels of 0,5 and $10 \%$, besides the combination of moringa +

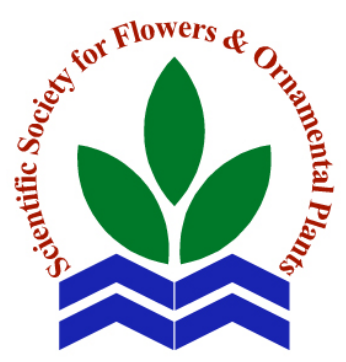

Scientific J. Flowers \& Ornamental Plants, 2(2):183-192 (2015).

Received:

27/8/2015

Revised by:

Prof. Dr. E.S. Nofal, Kafr El-Sheikh Univ.

Prof. Dr. Boshra A. ElSayed, Hort. Res. Inst., ARC. marjoram, moringa + thyme and marjoram + thyme extracts at $2.5 \%$. All of them were applied as a foliar spray commencing from November $20^{\text {th }}$ in both seasons on transplants of 14-15 cm. height with 4-5 leaves till June $20^{\text {th }}$ of the next year at 15 days interval. The plants were grown in sand + peatmoss mixture $(1: 1, \mathrm{v} / \mathrm{v})$ under the condition of saran house of $65 \%$ shading. The results could be briefed as follows:

Most plants which received the highest natural extract level $(10 \%)$ died after about six times of the beginning of spraying. So, the corresponding data of such treatments were excluded.

The prevalence of supplying plants with moringa extract at $5 \%$ for improving vegetative growth and root parameters of Artocarpus heterophyllus Lam. plant at the terminate of experiment (July $15^{\text {th }}$ ) as it increased leaf area, fresh and dry weights of either leaves or roots/plant. Also, it raised root length, root diameter, number of the secondary roots/ plant, length of the longest secondary root. Meanwhile, using the combination of marjoram + thyme extracts at $2.5 \%$ belonged to the first and second degree for improving the above mentioned traits in most cases. In contrast, the least scores were a result of untreated plants (control) and plants which received only thyme extract at $5 \%$.

From the aforementioned results, it could be recommended to apply either moringa extract at $5 \%$ or the combination of marjoram + thyme extracts at $2.5 \%$ on Artocarpus heterophyllus Lam. transplants for improving vegetative growth and root parameters of such economic important plant, besides, getting better plants without being forced to use chemical nutrients or synthetic growth regulators that may pollute the environment with getting a safe clean product.

Key words: Artocarpus heterophyllus, vegetative growth, Moringa oleifera, Thymus vulgaris, Majorana hortensis extracts. 


\section{Amira S. Soliman}

\section{INTRODUCTION}

Artocarpus heterophyllus Lam. (Jack fruit) is belonged to family Moraceae. It is native to parts of southern and southeast Asia. Jack fruit is the National fruit of Bangladesh. Jack fruit is also found in East Africa. It is well suited to tropical lowlands, and its fruit is the greatest tree-born fruit reaching as much as $36 \mathrm{~kg}$ in weight and up to $90 \mathrm{~cm}$ long and $50 \mathrm{~cm}$ in diameter. The seeds may be boiled or backed like beans. Seeds from ripe fruits are edible. They have a milky, sweet taste. The wood of the tree is used for the production of musical instruments. Jack fruit wood is widely used in the manufacture of furniture, doors and windows (Wikipedia, 2011).

In Egypt, Jack fruit (Artocarpus heterophyllus, Lam.) is considered as an important economic plant, but suffer variable conditions to be maintain good quality especially at the early growth stages, besides the slow rate of vegetative growth, consequently the delay of fruiting time.

It is well known that the use of natural extracts of certain plants (referred to as biostimulants, botanical activators or botanicals) in improving the growth of agricultural crops is highly recommended as environment friendly and safe approach to get better plants without being forced to use chemical nutrients or synthetic growth regulators that may contaminate the environment.

Moringa oleifera, family Moringaceae is most widely grown. Since leaves of moringa are rich in zeatin, it can be used as natural source of cytokinins (Fuglie, 1999). In addition moringa leaves is also rich in ascorbates, caroteniods, phenols, potassium and calcium which have plant growth promoting capabilities and often applied as exogenous plant growth stimulator (Foidle $e t$ al., 2001). Antioxidant such as ascorbic acid and glutathione which are found at high concentrations in moringa chloroplasts and other cellular compartiments are crucial for plant defense against oxidative stress
(Noctor and Foyer, 1998). In view of all these reports, it is hypothesized that priming with leaf extract from moringa, having a number of plant growth promoters, mineral nutrients and vitamins in a naturally balanced compositions which may promote the plant growth.

Thymus vulgaris, L. family Lamiaceae is native to Mediterranean countries, growing abundantly over wide area in France, Spain, Portugal, Italy, Algeria and Morocco (Porte et al., 2000). Moreover, it is also cultivated in other parts of Europe and North America, North Asia and Ocrania (Prubhi, 1976). Thyme is employed to season and suppress offensive odors, such as trimethylamino odor, in foods (Porte et al., 2000 and Prubhi, 1976).The essential oil is well recognized for its medicinal properties in the treatment of bronchitis, whooping cough and tooth-ache. The herb or its infusion is also given for several disorders. It is possible that the flavonoids present may be important, such as in the spasmolytic activity of the smooth muscles of the Guinea pig ileum and trachea (Prubhi, 1976 and Nakatani et al., 1989). It was found that the main components of the essential oil were thymol and carvacrol and that it had antimicrobial activity against fungi (some aflatoxins producers), virus, helminthes, Gram positive bacteria and Gram negative bacteria (Nakatani et al., 1989 and Farag et al., 1989).

Majorana hortensis Moench, (Marjoram) family Lamiaceae. Marjoram is indigenous to the Mediterranean area, it is a member of the Origanum genus, and stimilarity of flavor with oregano (Origanum vulgar). It has a strong and sharp spicy odor, Marjoram is a perennial evergreen shrub (treated as an annual under cultivation) growing to a height of about $40 \mathrm{~cm}$. It has a square, red brown stem and small and hairy, gray-green leaves. During summer, the plant produces tiny, white to pink flowers. The parts used, is the whole plant. The useful compounds are caffeic and rosmarinic acid, carvacrol, flavonoids, linalool, sterpenes 
triterpenoids, sabinen, sabinen hydrate (Health from Nature, 2011)

As for the very limited investigations were performed on the effect of natural extracts of the above mentioned plants, especially thyme or marjoram on vegetative growth and root parameters of woody or ornamental plants, the following findings may reveal some results which were gained on other plants in this regard. Foidle et al. (2001) reported that spraying the leaves of many field crops with moringa leaves extract (MLE) diluted with water produced some notable effects such as heavier stem and leaves. However, many authors attributed the beneficial effect of moringa extract to its content of zeatin, ascorbates, phenolic compounds, $\mathrm{K}$ and $\mathrm{Ca}$ (Makkar et al., 2007). El-Bassiouny et al. (2005) reported that foliar spray with $\alpha$-tocopherol (one of the components of thyme extract) on faba bean plants induced increase in growth parameters. Parabhu et al. (2010) worked on searled basil (Ocimum sanctum) and concluded that spraying the combination of $2 \%$ panchakavya $+0.2 \%$ humic acid $+2 \%$ moringa leaf extract resulted in higher plant height and number of leaves. Furthermore, the same treatment produced also a pronounced effect on fresh and dry herb weight. Mvumi et al. (2012) on Lycopersicon esculentum stated that moringa extract increased growth of the plant. Rana et al. (2013) experimented the effect of moringa leaf extract (MLE) on seedling growth of maize (Zea maize, L.) where different concentrations of MLE (5, 10,15 and $20 \%$ ) were used, and the different treatments were applied at two times ( 5 and 10 days (after sowing). Results indicated that application of $5 \%$ MLE at 5 days furnished maximum shoot length and fresh and dry weights per seedling.

Root parameters were also affected by natural extracts as mentioned by many authors. Foidle et al. (2001) reported that spraying the leaves of many field crops with moringa leaf extract (MLE) diluted with water produced some notable effects such as heavier roots. Phiri (2010) worked on major cereals maize (Zea maize, L.) where the seeds were treated with Moringa oleifera leaf extract at the ratio of $1: 10(\mathrm{w} / \mathrm{v})$ by a foliar spray. Results revealed that Moringa oleifera increased radical length of maize root by $77.8 \%$. Lobna et al. (2015) on jojoba reported that the addition of moringa leaves extract $(3.5,7$ and $10 \%)$ positively affected the studied growth characters i.e. length of roots and its fresh and dry weights, Muhammed (2015) investigated the comparative efficacy of different priming techniques and their effect on seedling growth and development of cluster bean. Cluster been seeds were subjected to hydro priming, on farm priming, halo priming with $1 \% \mathrm{KNO}$, and priming with two concentrations $(2 \%$ and $5 \%)$ of moringa leaf extract as experimental treatments. A control treatment was kept in comparison. The results revealed that priming with $9 \%$ moringa leaf extract increased final germination percentage (90\%) along with better root length. Priming with 5\% moringa leaf extract also gave significantly higher root fresh weight and it was followed by $2 \%$ moringa leaf extract. Hydro priming performed better than on-farm priming and halo priming with $1 \% \mathrm{KNO}$, but was much less significant than either concentration of moringa leaf extract.

Therefore, the present experiment was conducted with the aim of determining the most efficient natural extract treatment that can be applied for Artocarpus heterophyllus Lam. for producing plants of healthy vegetative growth at the early growth stages of such important economic plant.

\section{MATERIALS AND METHODS}

The present experiment was conducted throughout two successive seasons (2012/2013 and 2013/2014) at the nursery of Horticulture Research Institute, Agriculture Research Center, Giza, Egypt. The second season was an exact repition of the first one. It was intended to study the response of Artocarpus heterophyllus, Lam. transplant to different levels of Moringa oleifera Lam., 
Thymus vulgaris L., and Majorana hortensis, Moench extracts $(0,5$ and $10 \%)$ and some combinations (moringa + marjoram, moringa + thyme and marjoram + thyme extracts at $2.5 \%$ ) on vegetative and root growth parameters for producing transplants of vigorous growth.

\section{Plant material:}

Seeds of Artocarpus heterophyllus Lam. were collected from Zohria Garden in both seasons.

The mixture of sand + peatmoss $(1: 1$, $\mathrm{v} / \mathrm{v}$ ) was used in plantation in every season, as a preliminary study was conducted on the effect of some growing media on germination and early growth of newly established plants concerning, sand, peatmoss and the mixture of sand + peatmoss $(1: 1, \mathrm{v} / \mathrm{v})$, where the later proved its mastery in this regard.

Some physical and chemical properties of the used sand (fine sand granules with diameter of 0.20: $0.25 \mathrm{~mm}$ ) and chemical properties of peatmoss are shown in Tables (a) and (b), respectively.

Natural extracts: Different natural extracts of some plants with different levels (Moringa oleifera Lam., Thymus vulgais, L. and Majorana hortensis Moench) and some combinations were applied in both seasons, as follows:

1- Untreated plants (control)

2- Moringa extract at 5\%

3- Moring extract a at $10 \%$

4- Marjoram extract at 5\%

5- Marjoram extract at $10 \%$

6- Thyme extract at 5\%

7- Thyme extract at $10 \%$
8- Moringa + marjoram extracts at $2.5 \%$

9- Moringa + thyme extracts at $2.5 \%$

10 - Marjoram + thyme extracts at $2.5 \%$

\section{Preparation of extracts:}

Fresh leaves of moringa (Moringa oleifera, Lam.), thyme (Thymus vulgais, L.) and marjoram (Majorana hortensis, Moench) were collected directly from mature trees and plants. The sample was cleaned by rinsing bath in a distilled water, dried by shaking vigorously with hand. The leaves of every species were air dried in shade place. After drying, the leaves were ground by an electrical grinder and made powder. The powder was weighed and mixed with a distilled water at a ratio of 1:10 (w/v) i.e. $100 \mathrm{~g}$ powder $+1000 \mathrm{~cm}^{3}$ distilled water for preparing $10 \%$ aqueous extract. The mixture was then shaken for four hours by an electrical stirrer and kept in dark room temperature for $24 \mathrm{~h}$. Thereafter, the solution was heated till just before boiling. Afterwards, it was filtrated through two cheese cloth. The extracts served as the stock solution $(10 \%)$ for each plant species, where different levels of natural extracts $(0,2.5,5$ and $10 \%$ ) were prepared, using the crude aqueous extract of $10 \%$ of each and distilled water.

\section{Chemical composition of plant extracts:}

Moringa oleifera Lam.: The chemical composition of Moringa oleifera oil: hemacosan $(13.9 \%)$, pentacosan $(13.3 \%)$ and heptacosan $(11.4 \%)$ are the main components Ultra high performance chromatography. DAD analysis detected the flavonoids quercetin $(126 \mathrm{mg} / \mathrm{g})$ and luteolin $(6.2 \mathrm{mg} / \mathrm{g})$, The essential oil exhibited a relatively low free radical scavening capacity (Titiana et al., 2013).

Table a. Some physical and chemical analysis of the used sand.

\begin{tabular}{|c|c|c|c|c|c|c|c|c|c|c|c|c|c|c|c|c|}
\hline \multirow{2}{*}{ pH } & \multirow{2}{*}{$\begin{array}{c}\text { E.C. } \\
\text { (ds } / \mathbf{m})\end{array}$} & \multirow{2}{*}{ S.P. } & \multicolumn{4}{|c|}{ Cations (meq/l) } & \multicolumn{3}{|c|}{ Anions (meq/l) } & \multirow{2}{*}{$\begin{array}{c}\mathrm{N} \\
(\mathbf{p p m})\end{array}$} & \multirow{2}{*}{$\underset{(\mathbf{p p m}}{\mathbf{P}}$} & \multirow{2}{*}{$\begin{array}{c}\mathrm{K} \\
(\mathbf{p p m})\end{array}$} & \multirow{2}{*}{$\begin{array}{c}\text { Fe } \\
(\mathbf{p p m})\end{array}$} & \multirow{2}{*}{$\begin{array}{c}\mathrm{Zn} \\
(\mathbf{p p m})\end{array}$} & \multirow{2}{*}{$\begin{array}{c}\text { Mn } \\
(\mathbf{p p m})\end{array}$} & \multirow{2}{*}{$\begin{array}{c}\mathrm{Cu} \\
(\mathbf{p p m})\end{array}$} \\
\hline & & & $\mathrm{Ca}^{++}$ & $\mathbf{M g}^{++}$ & $\mathrm{Na}^{+}$ & $\mathbf{K}^{+}$ & $\mathrm{HCO}_{3}^{-}$ & $\mathrm{Cl}^{-}$ & $\mathrm{SO}_{4}^{--}$ & & & & & & & \\
\hline 7.41 & 1.51 & 42.30 & 2.94 & 1.29 & 3.89 & 2.30 & 3.54 & 4.73 & 2.16 & 232.40 & 25.05 & 580 & 7.48 & 5.66 & 2.90 & 7.18 \\
\hline
\end{tabular}


Table b. Some chemical properties of the used peatmoss.

\begin{tabular}{llll}
\hline Organic matter & $90-95 \%$ & $\mathbf{P}$ & $0.23 \%$ \\
Ash & $8-10 \%$ & K & $1.77 \%$ \\
Density (Vol. Dry) & $80-90 \mathrm{mg} / 1$ & Fe & $421 \mathrm{ppm}$ \\
pH value & 3.4 & $\mathbf{M n}$ & $27 \mathrm{ppm}$ \\
Water relation & $60.75 \%$ & $\mathbf{Z n}$ & $41 \mathrm{ppm}$ \\
Salinity & $0.3 \mathrm{~g} / 1$ & $\mathbf{C u}$ & $8.8 \mathrm{ppm}$ \\
$\mathbf{N}$ & $1.09 \%$ & $\mathbf{M g}$ & $3.3 \mathrm{ppm}$ \\
\hline
\end{tabular}

Thymus vulgais, L.: shows a polymorphic variations in monoterpene production, the presence of intraspecific chemotype variation being common in the genus Thymus. Each of the six chemotypes geraniol (G), $\alpha$-terpineol (A), thuyanol-4 (U), linalool- (L), carvacrol (C), and thymol (T), is named after its dominant monoterpene (Thompson et al., 2003).

Majorana hortensis, Moench: Volatile oil components (\%) of marjoram: alfa pinene $(1.57 \%)$, beta pinene $(4.79 \%)$, limonene $(9.63 \%), 1.80$ cineole $(5.22 \%), Y$ - terpinen $(2.23 \%)$, linalool $(3.88 \%)$, terpinen-4-ol (49.37\%), a-terpineol (9.38\%), linalyl acetate (2.39\%), estragol $(1.56 \%)$, beta carophyllene (2.21\%), eugenol (1.71\%), unidentified (6.06\%), (Parabhu et al., 2010).

\section{Procedure:}

In both seasons seeds of Artocarpus heterophyllus Lam. were planted on August $8^{\text {th }}$ in the mixture of sand + peatmoss $(1: 1$, $\mathrm{v} / \mathrm{v})$ in $20 \mathrm{~cm}$ diameter plastic pots under saran house condition of $65 \%$ shading. After two months from planting (October, $8^{\text {th }}$ ) where the newly established plants reached about 5-6 cm length, bearing 2-3 leaves, were transplanted into $20 \mathrm{~cm}$ diameter of plastic pots (one transplant each) filled with about $2.5 \mathrm{~kg}$ of the same mixture used in germination (sand/peatmoss $1: 1, \mathrm{v} / \mathrm{v}$ ) and left to grow under saran house conditions of $65 \%$ shading. Thereafter, when the plants reached about 14-15 cm length bearing 4-5 leaves (November $20^{\text {th }}$ ), foliar spray of the different natural extracts treatments were applied till rum off and then at 15 days interval till June $20^{\text {th }}$ of the next year. Besides, untreated plants (control) which received only foliar spray of distilled water. Thus, the plants were treated 15 times with foliar spray throughout the course of the study.

The layout of the experiment was a randomized complete block design (RCBD) with three replicates. Every experimental unit contained 4 plants and every treatment represented by 12 plants.

All the plants under various treatments received the usual agricultural practices, such as weeding, watering and fertilization ....etc. recommended for such plantation whenever required. In this connection, Kristalon (19:19:19) at the rate of $2 \mathrm{~g} / 1$ was applied at 15 days intervals as a soil drench, during the course of the study.

- At the terminate of the experiment $\left(\right.$ July $\left.15^{\text {th }}\right)$, the following data were recorded:

- Leaf area $\left(\mathrm{cm}^{2}\right)$.

- Fresh and dry weight of leaves (g).

- Length of the main root $(\mathrm{cm})$.

- Diameter of the main root (mm).

- Fresh and dry weights of the main $\operatorname{root}(\mathrm{g})$.

- No. of secondary roots/plant.

- The length of the longest secondary $\operatorname{root}(\mathrm{cm})$.

Data were then tabulated and statistically analyzed using SAS Computer Program (1994) and means were compared by L.S.D. test according to Snedecor and Cochran (1980).

\section{RESULTS AND DISCUSSION}

\section{Effect of natural extracts on leaves parameter of Artocarpus heterophyllus Lam. (Table, 1):}

A positive significant influence on leaf area of Artocarpus heterophyllus was brought about as a result of supplying plants with the different natural extract treatments in most cases in both seasons. However, it could be mentioned that treating plants with 
Table 1. Effect of some natural extracts on leaves parameter of Artocarpus heterophyllus, Lam. on July $15^{\text {th }}$ in the two seasons $(2012 / 2013$ and 2013/2014).

\begin{tabular}{lcccccc}
\hline \multirow{2}{*}{ Extracts } & \multicolumn{2}{c}{ Leaf area (cm) } & \multicolumn{2}{c}{$\begin{array}{c}\text { Fresh weight of } \\
\text { leaves/plant }\end{array}$} & \multicolumn{3}{c}{$\begin{array}{c}\text { Dry weight of } \\
\text { leaves/plant }\end{array}$} \\
& $\mathbf{2 0 1 3}$ & $\mathbf{2 0 1 4}$ & $\mathbf{2 0 1 3}$ & $\mathbf{2 0 1 4}$ & $\mathbf{2 0 1 3}$ & $\mathbf{2 0 1 4}$ \\
\hline Control & 34.81 & 40.74 & 6.42 & 7.35 & 2.03 & 2.45 \\
Moringa at 5\% & 47.53 & 50.74 & 11.11 & 13.48 & 3.71 & 4.34 \\
Marjoram at 5\% & 44.78 & 47.15 & 9.10 & 10.84 & 2.91 & 3.00 \\
Thyme at 5\% & 36.77 & 44.74 & 7.97 & 8.87 & 2.31 & 2.96 \\
Moringa + marjoram at 2.5\% & 36.12 & 45.58 & 8.00 & 9.78 & 2.40 & 3.47 \\
Moringa + thyme at 2.5\% & 45.97 & 48.24 & 9.57 & 11.24 & 3.06 & 3.60 \\
Marjoram + thyme at 2.5\% & 46.12 & 49.58 & 10.57 & 12.42 & 3.38 & 3.85 \\
LSD at 0.05 & 2.752 & 2.120 & 1.657 & 1.925 & 0.498 & 0.603 \\
\hline
\end{tabular}

either moringa or marjoram extracts at $5 \%$ as well as applying the combination of either moringa + thyme extracts at $2.5 \%$ or that of marjoram + thyme extracts at $2.5 \%$ proved their superiority in raising leaf area over control and other used treatments.

Results of the effect of natural extract treatments on fresh weight of leaves/plant showed that treating plants with either moringa or marjoram extracts at $5 \%$ as well as with the combination of either moringa + thyme or that of marjoram + thyme extracts at $2.5 \%$ were the best treatments used for raising such trait in both seasons.

On the other hand, the highest records were obtained on dry weight of leaves/plant due to supplying plants with moringa extract at $5 \%$ in both seasons. Meanwhile, the second rank for raising the same parameter was belonged to plants which received the combination of either moringa + thyme or that of marjoram + thyme extracts at $2.5 \%$.

The aforementioned results show the beneficial effects of the different natural extracts used in improving vegetative growth parameters of the plant (on July $15^{\text {th }}$ ). However, such results might be understood in the light of the findings of many scientists, on other plant species. Fodile et al. (2001) reported that spraying the leaves of many field crops with moringa leaf extract (MLE) diluted with water produced some notable effects such as heavier stem and leaves, this substantiates its potential to be used as a foliar spray to accelerate young plant growth, especially under sub-optimal conditions. However, Makkar et al. (2007) attributed the beneficial effect of moringa extract to its contents of zeatin, ascorbates, phenolic compounds, K and Ca. Parabhu et al. (2010) worked on searled basil (Ocimun sanctum) and concluded that spraying the combination of $2 \%$ Panchakavya $+0.2 \%$ humic acid $+2 \%$ moringa leaf extract resulted in higher leaf area and leaf area index of basil both at 60 and 90 days after planting. Further, the same treatment also produced a pronounced effect on fresh and dry herb weight of both the stages of plant growth. Rana et al. (2013) experimented the effect of moringa leaf extract (MLE) on seedling growth of maize (Zea maize L.), where different MLE concentrations (5, 10, 15 and 20\%) were used. Results in seedling growth bioassay, application of 5\% MLE at 5 DAS furnished maximum shoot fresh and dry weight per seedling. Referring the beneficial effect of thyme, El-Bassiouny et al. (2005) reported that foliar spray with $\alpha$-tocopherol (one of the components of thyme) on faba been plants induced increase in growth parameters. 


\section{Effect of natural extracts on root parameters of Artocarpus heterophyllus Lam. (Table, 2):}

In the two seasons, the significantly heaviest fresh and dry weights of roots/ plant was a result of supplying plants with either moringa extract at $5 \%$ or with the combination of marjoram + thyme extracts at $2.5 \%$. Treating plants with moringa extract at $5 \%$ proved its mastery in raising root length, comparing with that obtained from control and other treatments used. However, supplying plants with the combination of marjoram + thyme extracts at $2.5 \%$ came significantly in the second position in raising the same trait in both seasons. The highest records of root diameter were obtained due to supplying plants with either moringa extract at $5 \%$ or the combination of either moringa + marjoram or that of marjoram + thyme extracts at $2.5 \%$. Great influence on number of secondary roots/ plant was observed due to treating plants with moringa extract at $5 \%$ in both seasons. Meanwhile, the second position for raising such trait was achieved by supplying plants with the combination of moringa + thyme extracts at $2.5 \%$. Treating plants with either moringa extract at $5 \%$ or the combination of marjoram + thyme extracts at $2.5 \%$ recorded the utmost high values of the length of the longest secondary root in both seasons.

Results of the effect of various natural extract treatments on root parameters in the current study indicated the prevalence of supplying plants with moringa extract at 5\% followed by that of the combination of marjoram + thyme extracts at $2.5 \%$ in most cases. However, a lot of workers obtained a positive influence of these treatments on other plants. Foidle et al. (2001). reported that spraying the leaves of many field crops with moringa leaf extract (MLE) diluted with water produced some notable effects such as heavier roots. Phiri and Mebewe (2010) added that moringa extract increased radical length by $4 \%$ in beans. Phiri (2010) worked on major cereals maize (Zea maize L.), where the seeds were treated with Moringa oleifera leaf extract at the ratio of 1:10(w/v) by a foliar spray. Results revealed that Moringa oleifera increased radical length of maize by $77.8 \%$. Moreover, he attributed the beneficial effect of moringa leaf extract in improving root traits to the presence of various growth promoters as well as macro and micro elements in such organ. Mvumi et al. (2012) evaluated the effect of Moringa oleifera extract as a growth hormone on growth of tomato (Lycopersicon esculentum L. var Rodade). Five treatments were used: the control, where only water was added (MO), second control when ethanol $80 \%$ was added (ME), moringa extract applied once at 2 weeks from emergence $\left(\mathrm{M}_{1}\right)$, moringa extract applied 2 and 4 weeks from emergence $\left(\mathrm{M}_{2}\right)$, and moringa extract applied every 2 weeks starting from germination. Results showed that moringa extract significantly increased root dry matter weight. Rana et al. (2013) experimented the effect of moringa leaf extract (MLE) on seedling growth of maize (Zea maize, L.), where different MLE concentrations (5, 10, 15 and 20\%) were used. A distilled water (control) maintained for comparison. The different treatments were applied at two times (5 and 10 days) after sowing. Results in seedling growth bioassay furnished maximum root length and root fresh and dry weights per seedling. Lobna et al. (2015) worked on jojoba plants and mentioned that the addition of moringa leaves extract $(3.5,7$ and $10 \%$ ) positively affected the studied growth characters, i.e. length of roots, fresh and dry weight of roots. Muhammed (2015) worked on seedling growth of cluster bean (Cyamopsis tetragonoloba L.) and concluded that the maximum root length $(23.2 \mathrm{~cm})$ was given by $5 \%$ moringa leaf extract priming and it was followed by $2 \%$ moringa leaf extract $(22.6 \mathrm{~cm})$. He added that the significantly higher root length was recorded by moringa leaf extract which might be due to the presence of various growth promoters as well as macro and micro nutrients in moringa leaf extract. With regard to the beneficial effect of thyme, El-Bassiouny et 
Amira S. Soliman

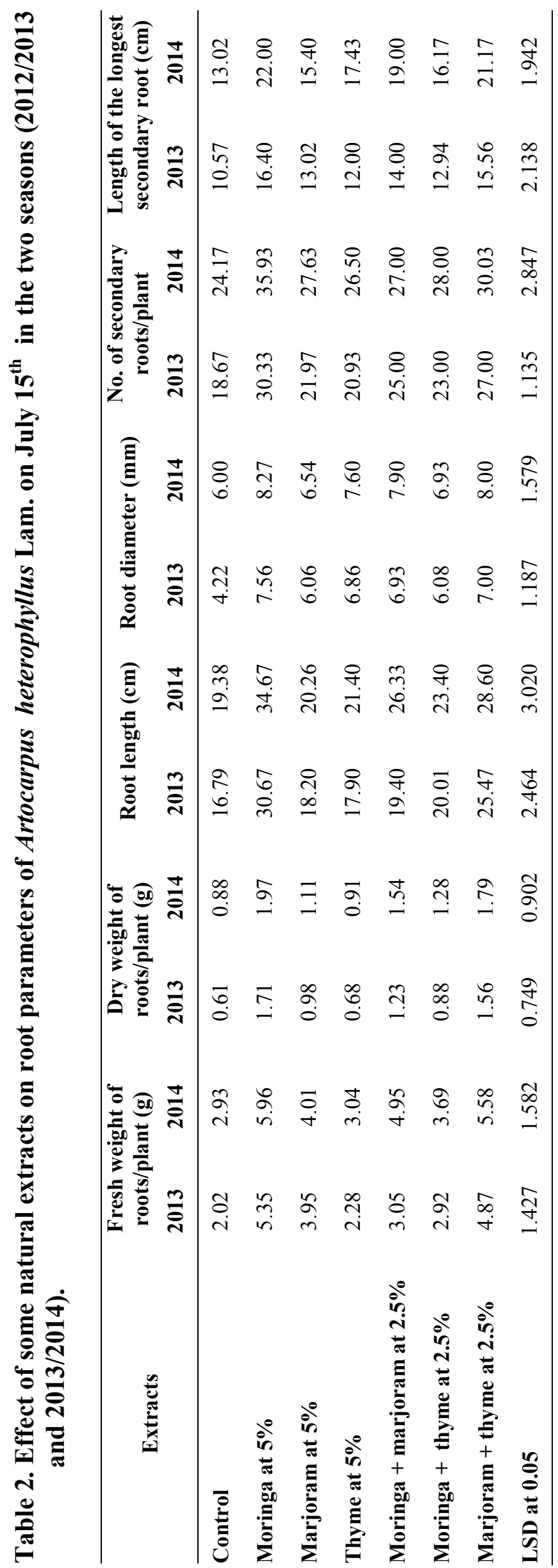


al. (2005) reported that foliar spray with $\alpha$ tocopherol (one of the components of thyme) on faba been plant induced increase in growth parametrs.

\section{REFERENCES}

El-Bassiouny, H.M.S.; Gobarah, M.E. and Ramadan, A.A. (2005). Effect of antioxidants on growth, yield, savism causative agents in seeds of Vicia faba L. plants grown under reclaimed sandy soils. J. Agric. Pak., 7(4):653-659.

Farag, R.S.; Daw, Z.Y.; Hewedi, F.M. and El-Baroty, G.S. (1989). Antimicrobial activity of some Egyptian spices essential oil. J. Food Protection, 52(9):665-667.

Foidle, N.; Makkar, H.P.S. and Becker, K. (2001). The potential of Moringa oleifera for agricultural and industrial. In, Fuglie L.J. (Eds). The Miracle Tree. Multiple Attributes of Moringa., 45-76 Wageningen, Netherlands.

Fuglie, L.J. (1999). The Miracle Tree, Moringa oleifera. Natural Nutrition for the Tropics. Church World Service, Paka., p.68.

Health from Nature (2011). Marjoram (Origanum majorana). http://web.archi ve.org/web/20130319135722/http://healt h-from-nature.net/Marjoram.html.

Lobna, S.; Taha, Hanan; Taie, A.A. and Hussein, M.M. (2015). Antioxidant properties, secondary metabolites and growth as affected by application of putrescine and Moringa leaves extract on Jojoba plants. Journal of Applied Pharmaceutical Science, 5(1):30-36.

Makkar, H.P.S.; Francis, G. and Becker, K. (2007). Bioactivity of photochemicals in some lesser known plants and their effects and potential applications in livestock and aquaculture production systems. Animal, 1:1371-1591.

Muhammad, A.I. (2015). Cluster bean (Cyamposis tetragonoloba L.), germination and seedling growth as influenced by seed invigoration techniques. American- Eurasian. J. Agric. \& Environ. Sci., 15(2):197-204.

Mvumi, C.; Fanuel, T. and Chiteka, A.Z. (2012). Effect of moringa extract on growth and yield of tomato. Greener Journal of Agricultural Sciences, 2(5):207-211.

Nakatani, N.; Miura, K.; and Inagaki, T.; (1989). Structure of new deodorant biphenyl compounds from thyme (Thymus vulgaris L.) and their activity against methyl mercaptan. Agric. Biol. Chem., 53:1375-1381.

Noctor, G. and Foyer, C.H. (1998). Ascorbate and glutathione keeping active oxygen under control. Ann. Rev. Plant Physiol. Plant Mol. Biol., 49:249-279.

Parabhu, M.; Ramesh Kumar, A. and Rajamani, K. (2010). Influence of different organic substances on growth and herb yield of scrad basil (Ocimum sanctum L.). Indian J. Agric. Res., 44(1):48-52.

Phiri, C. (2010). Influence of Moringa oleifera leaf extracts on germination and early seedling development of major cereals. Agric. \& Biol. J. N. Amer., 1(5):774-777.

Phiri, C. and Mebew, D.N. (2010). Influence of Moringa oleifera leaf extracts on germination and seedling survival of three common legumes. International Journal of Agriculture \& Biology, 12(2):315-317.

Porte, A.; Godoy, R.; Lopes, D.; Koketsu, M.; Torquilho, S.L. and Torquilho, H. (2000). Essential oil of Rosmarinus officinalis L. (rosemary) from Rio de Janerio, Brazil. J. Essent. Oil Res. 12:577-580.

Prubhi, J.S. (1976). Spices and Condiments. National Book Trust, New Delhi., 199 pp.

Rana, N.A.; Tauveer, A.; Abdul, K.; Iqbal, A.; Chaffari, A.R.; Matloop, A. and Maqsood, Q. (2013). Maize (Zea maize, 


\section{Amira S. Soliman}

L.) germination, growth and yield response to foliar application of Moringa oleiferaLam leaf extract. Crop \& Environment, 4(1):39-45.

SAS Computer Program (1994). SAS/ STAT User's Guide: Statistics vers. 604, $4^{\text {th }} \mathrm{Ed}$, SAS Institute. Inc., Cary, N.C. U.S.A.

Snedecor, G.W. and Cochran, W.G. (1980). Statistical Methods $6^{\text {th }}$ ed., Iowa State Univ. Press, Ames. Iowa, U.S.A.

Thompson, J.J.; Chalcha, A.; Michet, Y. and Ehlers, B.L. (2003). Qualitative and quantitative variation in monoterpene cooccurrence and composition of the essential oil of Thymus vulgaris chemotypes. J. Chem. Ecol., 29(4):859880 .

Titana, M.; Nazarro, F.; Mancini, E.; Fratianni, F.; Coppola, R.; Martino, L.D.; Agostinlo, A.B. and Vincenzo, D.F. (2013). Chemical composition and biological activity of the essential oil from leaves of Moringa oleifera Lam. cultivated in Mozambique. Molecules, 18:10989-11000.

Wikipedia (2011). Jack Fruit. Cited in http://www.Wikipedia.com.

\section{إستجابة نبات الجالك فروت (الكاكايا) Artocarpus heterophyllus Lam لبعض المستخلصات

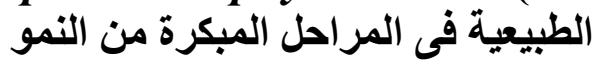

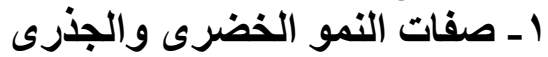

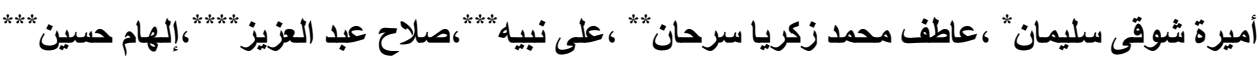

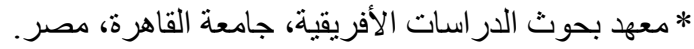

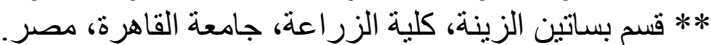

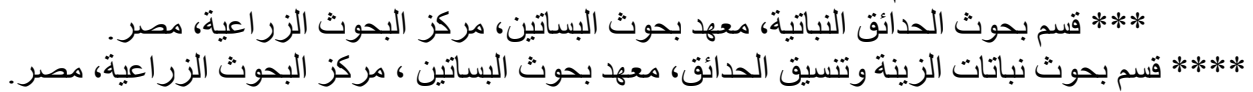

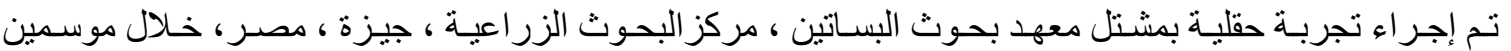

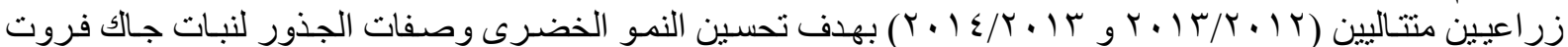
Artocarpus heterophyllus, Lam.

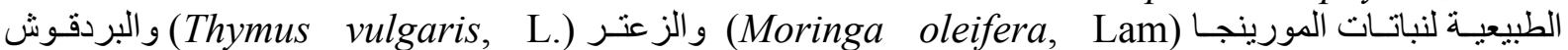

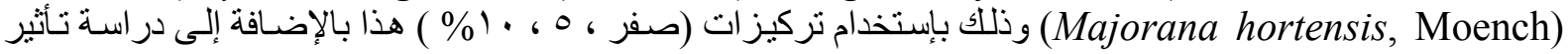

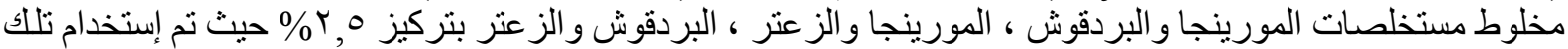

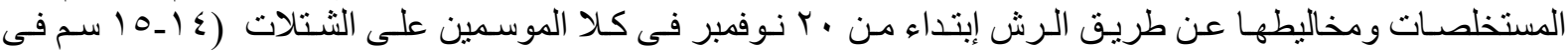

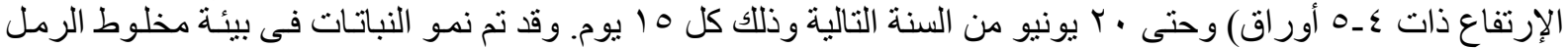

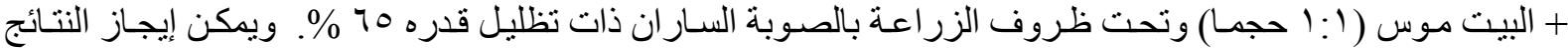

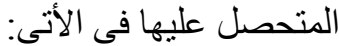

بداية أدى إستخدام تركيز • 1\% من المستخلصات الطبيعية السابقة إلى موت معظم النباتات بعد 7 رشـات من بداية الرش ولذلك فقد تم إستبعاد البيانات المتحصل علئ عليها من تلأك المعاملات.

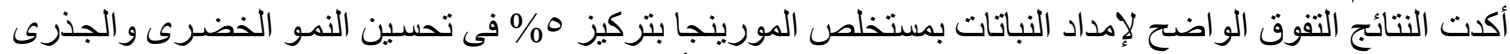

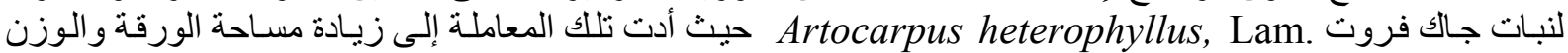

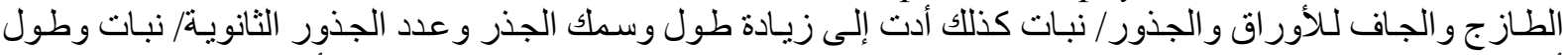

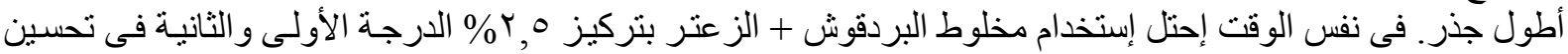

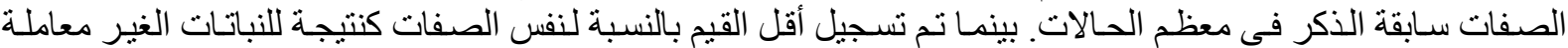

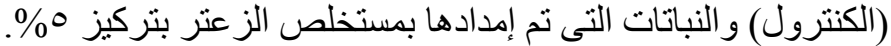

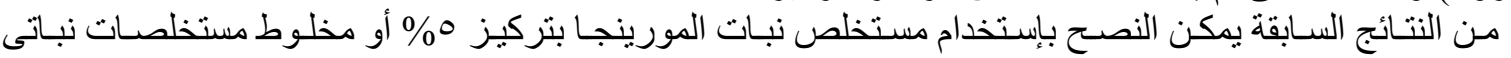

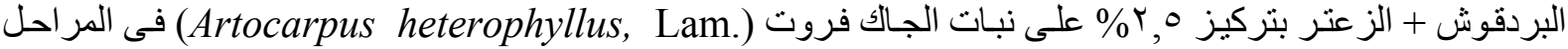

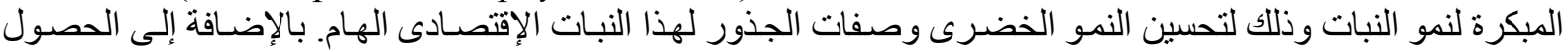

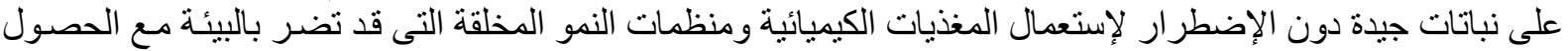

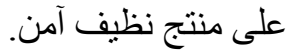

